DOI: $10.21847 / 1728-9343.2019 .4(162) .177234$

LOMACHINSKA IRINA,

Borys Grinchenko Kyiv University (Kyiv, Ukraine)

e-mail: lomachinskairina@ukr.net, ORCID 0000-0003-2537-6322

KHRYPKO SVITLANA,

Borys Grinchenko Kyiv University (Kyiv, Ukraine)

e-mail: s.khrypko@kubg.edu.ua, ORCID 0000-0001-9426-4549

IATSENKO GANNA,

National Shipbuilding University named after admiral Makarov (Mykolayv, Ukraine)

e-mail:iats2601@gmail.com,ORCID0000-0002-8675-5118

\title{
TRANSFORMATION OF UKRAINIAN NAME-GIVING PROCESS: HISTORICAL ANALYSIS
}

The issue is devoted to a value sphere of Christian dominant consideration in the spiritual and semantic space of a name-giving culture in Ukrainian anthroponymic tradition as well as to the historical and philosophical analysis of spiritual peculiarities presented in the process of proper nouns' creation and functioning in Ukrainian spiritual culture at the pagan times. The urgency of an issue has been intensified by a fact that a name is one of the most crucial symbols in human's awareness of personal solitude. Anthroponyms (human proper nouns) have been a widely used national lexical phenomenon for different times and epochs, and for different people, that emphasized a constant existential need of the issue in the individual as well as in the social consideration. The sphere of a scientific study is the genesis and peculiarities of Ukrainian onomasticon. The ancient names' popularity and the general understanding of the true name's spiritual roots of an ancient name are discussed. The crucial concept of the work is a statement about the preservation of the spiritual sources of a pagan tradition. National Ukrainian onomasticon has been predominantly formed on the Orthodox value basis that is owing to the historical peculiarities of the national, religious and cultural space. The value of a name as a philosophic, cultural, spiritual and historical phenomenon is highlighted. The aim of an issue is to represent a transcendental peculiarity of the proper names and via a structured analysis with the hermeneutic methodology application to highlight the appearance and spiritual components in the elite-sacral, elite-secular and national names in Ukrainian ancient ethical tradition. The cardinal meaningful lines of the names' spiritual roots are to be analyzed. The conclusions of the issue are embodied in the following statements and constants:

- A name is the most essential expression of self on an ontological level.

- A name is an opportunity of social memory saving on a social level.

- The two level context of Ukrainian onomasticon is represented by a pagan tradition of namegiving which is based on the spiritual unity between a human and natural environment that transforms it into a spiritual charm.

- Christian tradition of name blessing considers a name as a spiritual protection of a saint as well as a motivation for further spiritual changes.

Key words: a name; a proper name; philosophy of a name; Christian tradition of a name; spirituality; spiritual tradition; anthroponymic; ethnical culture.

\section{Introduction}

The philosophy of name is a crucial aspect of the social reality's symbolic dimension; it reveals an attempt to combine in a unity all principles of name giving process in a close connection with transformational processes of social and cultural being. A name is a specific sense of being, simultaneously, it reflects all national archetypes and is a social system's embodiment, moreover it is able to transform symbolic reality and become an individual myth. A name is an essence beyond individual limits, it standardizes social and communication sphere via the influence on a system of statuses' and roles' interconnec- tion. The name's symbolism determines social information and communication systems due to a current language, it highlights the markers of "the own and the foreign" that develop inner social space. The names can be considered as collective samples of symbolic codes which embody social traditions and values, participate in a national archetype development.

A name is something what "is given", what "bears", "what are proud of", "what can be lost", and for the honor of which "argue", and sometimes "fight"... A name is a particular man's title that is given to a person at birth. It is a main feature of a person which becomes his symbol. A 
name's misspelling can be a reason for a serious offence, a motivation for individual conflict. A name is a word of "a serious consideration, which is addressed to a person, however, primarily, a name accompanies a human's life" (Savitska, 2012: 5). A national tradition is embodied into a name that becomes precious and eternal heritage, the lack of which eliminates any future.

As T. Shibutani mentioned, a name was one of the most crucial symbol in a human existence understanding: "A symbol used for a personal determination is closely associated with his self; consequently people frequently mix a name with its owner as a name is a real human being" (Shibutani, 2007: 261). The functional goal of proper nouns in symbolic social structure was determined by ethnical, historical, religious and cultural features; simultaneously the most meaningful are the following: an individual symbol (is for a particular person determination), a social symbol (indicates status and role position), a national symbol (transmits connections between different generations and forms social memory), a sacral symbol (provides spiritual protection).

The aim of an issue is to represent a transcendental peculiarity of the proper names and via a structured analysis with the hermeneutic methodology application to highlight the appearance and spiritual components in the elite-sacral, elite-secular and national names in Ukrainian ancient ethical tradition. The cardinal meaningful lines of the names' spiritual roots are to be analyzed.

The issue presents the second part of the study ${ }^{1}$ where the Christian dominant has been added to an ancient pagan description of the names. The authors' conception of names' description was based on the linearity of historical process according to which the Christianity adoption had profoundly changed the pagan traditions, general way of life, and as a consequence the whole process of namegiving.

\section{Methods}

Methodology of the study is based on the following methods: a comparative-historical method is applied for the peculiarities determination of a name-giving process in the works of the philosophers connected with the Orthodox Church. A descriptive method is used to highlight the national components of a name-giving process. Moreover structured analysis with the hermeneutic methodology application is used to highlight the appearance and spiritual components in the elite-sacral, elite-secular and national names in Ukrainian ancient ethical tradition. Furthermore, according to the aim of the national names' heritage demonstration, a linguistic analysis of names' suffixes, prefixes and roots is provided in order to illustrate the processes of meaning modifications.

\section{Results and Discussions}

Anthroponyms (human proper nouns) have been a widely used national lexical phenomenon for different times and epochs (Gerasimchuk, 2002: 3). A nation is alive while national names have lived; a person is still alive in human's memory while his name has not been forgotten. Anthroponyms have not only become historical witnesses, but historical milestones (as for the names human history can be learnt). A name has always been equated with

\footnotetext{
1 The first part of the study of name-giving process in Kyiv Rus during the pagan times was published by Khrypko S., latsenko G. in BEYTULHIKME: An International Journal of Philosophy (2019).
}

something or somebody, according to ancient beliefs: a name is an essence of a thing and a man, namely it is a defining sign of a person; in other words nothing exists until a necessity in a name arises, and vice versa, when a necessity appears to destroy something completely, erase from memory the form-spell is used, for instance: "I wish his name do not exist anymore" (Zajvoronok, 2006: 261). In this case we can address to modern versions of angry statements to compare: "I wish I haven't heard his name!" or "Forget his name!" etc.

A history maintained a mystery of eternal desire to "inscribe a name". A name was kept into the symbols, signs, charm codes, in the culture of name giving, etc. The fact of name knowing was compared to the fact of power obtaining over a person whose name was known. Consequently, a name and everything connected with it possessed powerful mystical influence and meaning. Moreover, a name's role in name-giving culture and prayers' practices is crucial (Zajvoronok, 2006: 261).

The civilizations have arisen and gone, the times and epochs have changed, the values have been devalued in the historical kaleidoscope of events, nevertheless, in all historical races a right of all who have lived on the earth to have a personal name remains indispensable. The Antiquity has always been eloquent. According to Homer's "Odyssey" written about a thousand years before Anno Domini: "... in general without a name nobody is among people. Who comes into the world, a nobleman or a poor man, everyone will obtain a name from parents..." (Gerasimchuk, 2002: 7).

A name is treasure that a person will possess even if he loses everything. Nevertheless a name can be purposely changed when a life starts from the very beginning, as the values are the filling substance of the "micro world" of a person when "macro world" has temporarily lost its meaning. Values are the substance which in the tough situations of being surrounds a person by the subtle, unnoticed protection that gives the sense of human dignity incorporated into human nature. It is the essence of a word from which a life will begin when it begins from scratch.

The history of Ukrainian name-giving process as well as the history of scientific interest to the issue is multicontext. Ethno cultural context of Ukrainian anthroponomics history is considered by G. Lozko. The regional diversity of name-giving culture is presented in the works of Savitskyi's couple. The detailed analysis of Ukrainian onomasticon with Soviet peculiarity is presented by V. Gerasimchuk and A. Nechiporenko. The historical and cultural problematic practices on the issue are provided by N. Dziatkivska, I. Franko, S. Gubernachuk, L. Skripnik, I. Suchomlin. The particular attention should be paid to the well-developed collection of Ukrainian names elaborated by P. Chuchka, M. Khudash. The ethnical and symbolic diversity of ordinary context of names' usage can be traced in the works of G. Bulaschov, O. Buriak, O. Maschinets, S. Nalivaiko, O. Voropai, V. Zajvoronok and in other historical, ethnical and cultural studies.

Preserving spiritual sources of pagan culture Ukrainian national onomastic science was generally built on the Orthodox value bases that were formed within national religious and cultural space under peculiar historical circumstances. The Christian tradition of name's spiritual essence representation is provided into the works of patristic tradition representatives, namely it is typically for John Chrysostom and St. Augustine; a sacral meaning of a name is discovered in Russian Orthodox philosophy, namely in the works of S. Bulgakov, A. Losev, P. Florensky. 
The semantic and sacral leadership in the process of Ukrainian names' creation goes to such called "God given names", or "God glorification names". Such names are oriented on the idea of God glorification according to their sounding; the idea of names' derivation from God's will is followed.

The recurrent theme in name-giving culture had an idea of constant worship to God. The most part of the researchers paid attention to the kinship and other linguistic analogies between the word "the Slavs" and "glorification" (Lozko, 1998: 6). (The presented analogy is true for Ukrainian language)

It should be noticed that there is the biggest amount of preserved names in sphere of proper names which have a root Slav-: Dobroslav, Miroslav, Mstislav, Slavoiml, Slavomir, Sviatoslav, Viacheslav, Yaroslav, etc. There are names with semantic peculiarities, such as old names Slavibor (struggle glorification) and Slavoning (tenderness glorification) (Lozko, 1998: 107).

Historical memory highlighted the following tendency, namely the most popular were the names related to the theme of birth and God's givenness. The base of the words constructed by the root Bog- ("God") and Rod- ("Family"). Bogolub, Bogomol, Bogorod, Bogumir, Bozeslav, Bozko, Radomir, Rodoslav, etc. (Skripnik, 1996: 42). Some of the names are still popular nowadays. However the rest of them were transformed into the surnames.

The historical memory stated that Ukrainian ancient name's collection had its Olympus which was consisted of so-called noble names. The unique right to bear such names belonged to the secular or military nobility.

According to spiritual and valued features such names have complicated lexical filling and stand in one row with the bright names of Kyivskaya Rus, which is an evidence of word and name talents of our ancestors. These names are often comprised of two lexical roots, one of which is multi-meaning and has an ability to be composed with another roots (-bor, -chval, -dar, -gost, -lub, -mil, -mir, misl, -nig, -polk, -slav, -volod, -voi, -zar, etc.): Boguchval, Boguslav, Dobrolub, Dobromisl, Dorogost, Iziaslav, Ladimir, Lubomisl, Ludmil, Moioslav, Mstibog, Pakoslav, Pereiaslav, Radislav, Ratibor, Ratmir, Rogvolod, Rostislav, Sudomir, Svitozar, Vladislav, Vseslav, Voibor, Volodar, Vorotislav, Yaropolk, etc (Gerasimchuk, 2002: 8).

The same female version of the names was created from the male names' samples and they sounded like male ones: Boguslava, Boleslava, Goryslava, Ludmila, Myrodara, Vseslava, etc. In addition to the noticed melody of the names, the majestic spirit related to the noble dignity and virtues was put into them. Furthermore, they contained the prophetic sense given by the root "-Slav" which promised the future thunder glory to its holder.

There is an astonishing fact that there are 103 names with a root "Slav-" of total amount of 190 names in "Kyiv Rus Primary Chronicle". As the time had passed the history of names had gained the new traits and the short, "cut" variant of names appeared in which only the first part of it was taken: Boris (from Borislav), Vadim (from Vadimir), Rad (from Radimir), etc. The desire to harmonize names' sounding (as well as generate trust, love to their holders) created a tendency of names' reducing combined with usage of diminutive-hypocoristic suffixes. The result of the tendency could be noticed in the following names: Borynia (from Boryslava), Vischko (from Vischeslav), Yarun, Yarysch (from Yaroslav, Yaropolk), Zyriata (from Zyroslav), etc.

Tracing back in time into polysemantic history of Ukrainian name-giving culture, the following tendency can be stated: the inclusion of the ancient Russian names with Scandinavian origins to "the noble names", for instance, Askold, Dir, Igor, Olga, Oleg, Rognida, etc. Some of the historical names are widely spread nowadays. Furthermore, such modern and popular names as Bogdan, Ludmila, Tamila, Svitlana belong to the ancient, pagan names. The enumerated female names were generated from the male samples and became well spread only in the $20^{\text {th }}$ century. The name "Bogdan" deserves to separate attention. Having been a key name in the pagan times, it remained popularity in the Christian culture, and even in the period of militant atheism.

Ukrainian history preserved a distinguished page of folk names which were unique in linguistic and semantic context as they embodied ethnical fantasy, historical memory and mentality of the Ukrainians. Nature, routine environment and even some paradoxical spheres of life were the value references of folk names. Currently, they have come into the category of ethnical surnames. Conditionally, the following classification can be presented:

1. The specialized names connected with occupation: Bajan (Storyteller), Bava (a woman who looks after the children), Kozemiaka (Tanner), Kulynych (Baker), Pasichnik (Beekeeper), Pasko (Shepherd), etc.

2. The names embodied the social status, level of power of their holder: Bastar (Rich man), Diak (Clerk), Igumen (Hegumen), Mlyn (Mill's holder who used to possess great influence on country life), Posol (Ambassador), Vischun, Volvchv, Molf (Magician), Vladika (Lord), etc.

3. The territorial names connected with the human origins and ethnical characteristics: Bran (Captive), Cheremis, Mordvin, Podoroznik (Traveler who stayed), Pryimak (Adopted), Tatarin (Tatar), etc.

4. The names connected with the character or appearance traits which were aimed to be highlighted: Balakunia (Talkative), Batak (Obstinate), Bermiata (Person who is a burden) Kislytia (Crier), Rozumnik (a bright boy), Schulga (a left-handed man), Suvor (has a harsh character or appearance), Tugodum (is not bright in thinking), Ugrim (Moody), etc.

5. Zoonimy - the names which were originated from the animal, birds, fish, and insects names. They were included into the largest part of folk names. For instance: Baran (Sheep) Bdzola (Bee), Cryl (Krill), Gusak (Goose), Lel (Stork), Lin (tench), Mucha (fly), Pes (Dog), Ptacha (Bird), Solovei (Nightingale) Soroka (magpie), Vovk (wolf), Zaets (hair), Zuk (bug), Zur (Crane), etc. The nameszoonims were transformed into the family names, for instance: Bdzoliary (derived from bees), Levitchi (derived from lion), Lysitchi (derived from fox), Vedmeditchi (derived from bear), Volkovitchi (derived from wolf), etc. Further, they were accepted as surnames.

6. Phytonims -derived from the vegetation names: Garbuz (pumpkin), Goroch (pea), Kapusta (cabbage), Kvasolia (bean), Loza (vine), Zito (wheat), etc. It can be assumed that the sense of a folk song: "A pumpkin is walking through a vegetable garden and asking about his origins" depicts a real life of a Pumpkin's family. A pumpkin played a crucial role in Ukrainian traditional format of matchmaking. It might be a sign that this vegetable used to have a special semantic role which had been forgotten.

7. Numerals - are the names connected with the idea of desirable child's birth. In such big families the process of name-giving was rather simple - children got their names according to their birth position: Pervuscha or Pervak (the first), Vtoruscha (the second), Tretiak (the third), Chetvertak (the fourth), etc. 
8. The calendar names included Ukrainian ancient names of months: January - Triskun, Snigivyk, Liodovyk; February - Gromnik, Kruten; March - Zimobor, Berezol, Sochen; April - Tsviten, Krasnets, Snigigin; May - Travnik, Pisennik, Gromovik; June - Kresnik, Chervets, Izok; July Sinokis, Kosen, Grozovyk; August - Znyven, Kopen, Chlibochol, Spasivets; September - Siven, Veresnets, Revun; October - Vesilnyk, Zazimnyk, Padzernyk; November Padolyst, Napivzymnyk; December - Andriets (from Christian Apostle Andrew), Chmuren, Movchanets.

9. The names with emotional color, given according to the particular temperament. For instance, the names were given to a tiny child due to his character traits: Bezson (sleepless nights), Budylo or Budylko (to wake up), Buyan, Krik, Reva (cry), Gam (ruckus), Mazun (loves caress), Tyschenia (silent), Schumilo (to make noise), Slastion (sweet-tooth), Zvonilo or Zviaga (to ring up), etc.

10. The "strong" names embodied the aspiration to put life power into a holder: Dub (oak), Byk (bull), Zalizo (iron), Silan or Silobor (strong man), etc.

11. The "well-fed" names embodied the eternal parents' desire to secure child's fate, eliminate any calamity and poverty. The realization of such wish was in the following funny names: Borshch (beet soup), Bulba (potato), Salo (fat), Kascha (porridge), Kusen (a big part), Makota (from the word "smakota" - delicious), Pyrig (pie), etc.

12. The charm names were given to hide the prospective future of the children. A bad-sounding name was a particular spell against evil eye. Such tendency created a tendency of "malevolent" names: Bermiata (burden), Bida (calamity), Kara (punishment), Nechai or Nezdan (unexpected), Nevdacha (misfortune), Rozgildiaj (chimney sweep), etc. Moreover, one peculiarity should be mentioned according to the social status of a family, for instance, in poor family one unexpected child could bring despair, which is reflected in the process of name-giving. Additional attention should be drawn to the name "Bolvan", which had obtained negative connotation in the early Christian time, however it used to be one of the "noble" names as traced the origins from pagan "divine" light (bovvans were the sources of light). The charm functions had so called "frightening" names: Krakun (raven), Muchomor (fly agaric), Osa (wasp), Patsiuk (spider), Tsibulia (onion), etc.

13. The names which measured parents' love. Such names were incredibly tender, kind and good-sounding: Basko (handsome), Bazan (the most desired), Dana (was given), Kupava (girl who was born on the holiday of Ivana Kupala), Lipa (the best), Maluscha (the smallest), Zlatovlaska (with golden hair), etc. Parents' expectations to a child of being happy, bright, beautiful or handsome and rich were laid on the basis of "wished" names: Radechko (happy), Ranko (early), Semirad (extremely happy), etc. Parents' love embodied in the charm names had to protect all further life and influence on the level of luck on the life road.

Furthermore, it should be mentioned that a vast part of the names resembled the nicknames: Kysil (fruit jelly), Kuslytsia (sour), Zyrnos (fat), etc. The popularity of a nickname could displace a real name, as a result, a person was exceptionally known by a nickname. Ukrainian surnames derived from such nicknames. M. Gogol's heritage should be considered in this context. The author meticulously worked with Ukrainian anthroponyms and a complex of bright surnames in his works included the nicknames having taken from the real life: Bulba (popato), Dovgouch (a person with long ears), Motuzochka (rope), Remin (belt), etc.

The abovementioned list includes the most contexts of name-giving reasons. Having reviewed the list of the names which were given to children, we could consider that the vast majority of them belonged to the past and was not currently used. Nevertheless, the "noble" names have still been popular; however, so-called "folk" names have become surnames.

The era of creative fantasy and independence in a proper nouns' choice in Kyiv Rus had ended with the Christian faith and culture arrival. Christianity is a monotheistic religion that depicts a way to God via revelation of Love as well as it is a unique ideology that prescribes a way of life, moral principles, rites and traditions, one of which is baptism. Baptism has obtained the cardinal meaning of name-giving process. "To baptize", "to give a name" and "accept to the Christian community" were the synonyms. "To go for a name" was an ancient Christian tradition connected with a name's obtaining. A midwife went to a local priest with the gifts in order "to obtain a name". A name was corresponded to a name of a saint who was memorized on the date.

A name is unlimited by symbolic function in religious consciousness, however it is determined via the system of associations which creates an emotional attitude to its owner. Particularly, a name expresses some ideas and carries a symbolic as well as sacral meaning in religious symbolism.

The Christian tradition of name's consideration combined the antique roots with the Old Testament tradition, in which a name was considered not only as a simple symbolic set, but as a mysterious symbol that indicated the main characteristics of its owner and was in a close connection with him. A name is accepted as a full determination of a named object, or a person. A name does not have an abstract or theoretical character; it reveals vital and practical features in the Bible, particularly a name's meaning is not a verbal one, but an actual one. According to the biblical language a name is not a simple determination of a certain person or a particular object, it indicates the main characteristics of its owner, reveals the deep depths of the being and his place in the world. A name is mysteriously connected with a soul: when a name is pronounced, it rises to a soul of its owner. The Old Testament name's understanding does not only combine a set of sounds or letters for distinguishing one person from another, it appeals to human interconnections. To know someone's name means to establish a spiritual connection with a name's owner, to reveal his inner nature. In the Old Testament tradition a man is accepted due to the principle: "According to a name is human self" (1 Kings 25:25).

The philosophers of Antiquity payed the main attention to a name, that determined a particular item in a language. Socrates and Plato considered that a name was not randomly chosen, "not as we wished", however due to the nature. Nevertheless, what does it mean "according to the nature"? A name is a mean for any item identification for Plato (Plato, 1994). A name and object interconnections are consolidated by society. The described connection of a symbol with a determined item has further interpretation in St. Augustin's works: "the symbolic usage is aimed at items determination...", "any symbol is also an item; as if it is no item, it will be nothing" (St. Augustine, 2006: 44). A hidden moral and ethical sense should be searched in symbols, as: "it is he (Jesus Christ) who made us capable of serving the new covenant, which consists not of a written law but of the Spirit. The written law brings death, but the Spirit gives life" (2 Cor 3:6).

Comparing slavery to the Judean symbols' under- 
standing in the light of following the letter of the law, Augustine highlights that "Christian freedom liberates from symbols even those people for whom they were useful, ... as someone who honors a particular thing without its meaning understanding is a slave of symbols; nevertheless someone who honors the highest (divine) symbols... can be full of spiritual power even during the slavery" (St. Augustine, 2006: 134). Consequently, a name is only a symbol, if its owner has no desire to fill its essence with some spiritual sense.

A name reflects a historically stored spiritual system of national knowledge; as a result it possesses global religious, cultural and philosophical potential: "our entire national heritage has been stored in a single word and especially in a name for centuries... There is a meeting of all possible mental layers of being in a word and a name... There is a center of all physiological, psychological, phenomenological, logical, dialectical and ontological spheres in a name. It embodies a combination of human knowledge with all alien intelligent and unintelligent lives and beings" (Losev, 1994: 8).

The biblical names had special meanings in the light of divine mindset realization and the human way of attitude identification to God. Receiving a new name means a divine consecration, the establishment of new relations with God. According to the Orthodox doctrine every newcomer to Christian church should obtain a new Christian name, the beholder of which is considered to be saint. Such tradition appeared in the first centuries of Christianity, at that time when a lot of names were glorified by their holders via feats of martyrdom and righteousness. The neophytes were assumed to be tightly connected with God and a church, moreover, they were protected by the saints, whom they were obliged to follow. John Chrysostom mentioned in his $21^{\text {st }}$ conversation on the Book of Genesis that: "The Christians should contemplate the images of saints as an instance of virtue and bliss at the process of new names obtaining" (Chrysostom, 2001). To conclude the more active desire to follow the saints, the most powerful their protection can be received.

The Orthodox spiritual and religious heritage increasingly influenced on Ukrainian tradition of name giving. There is a tradition to give names on the honor of saints during baptism in Orthodox Christianity; hence the saints are called human angels. Such collocation indicates that a saint and a guardian angel are getting closer in their service to a man; they are determined by a common name (however they are not equated). Within spiritual state change which is considered as a new birth, a name is changed, for instance after having adopted vows a monk gets a new name and relies on a new saint-guardian. The saints were those who completed the self-God-like image "via their active faith feat and active love", as a consequence they attracted abundant God's grace" (Bulgakov, 1989: 261). The saints can help due to the spiritual freedom in love, which is achieved by a feat. It gives them protection power in front of God in a prayer as well as in active love to people (Bulgakov, 1989: 263).

Simultaneously, the Orthodox Church omits the names of Jesus and Virgin Mary (especially Mary of Virgin Mary for nuns) as they are worshipped. A name of Jesus can be mentioned only in a prayer as it contains special spiritual power and after a reference to it a heart is cleared: "In the name of Christ all negative and evil (author's) things are eliminated as wax in fire" (Simon the New Theologian, 1890: 190).

S. Bulgakov emphasizes the primary ontological sense of a name that means not only an essence of particular man's being, but humanity in general: "The names are the roots of diversity, the nests of being which are inherited in the whole humanity" (Bulgakov, 1953: 162). A name is given not in general in the Orthodox tradition, however as a particular characteristic's manifestation, and this quality feature does not remain neutral; on the contrary, the quantity of each kind of names corresponds to the names' actualization quantity. An angel guardianship is ontologically envisaged: a proper noun is connected with a common action, despite their difference. Therefore a name contains power and energy, it forms, establishes its owner: an owner has a name; however a name determines its owner as an inner reason, entelechy... A name is an idea as an image of contemplation; it is entelechy as power... Idea is an ideal base of entelechy, its essential root, entelechy is a particular essence of an idea, which is the energy, entelechy is its personification display at the same time" (Bulgakov, 1953: 160).

A name creates some energetic power, therefore "it is vital energy that is perceived by inner intuition which can be revealed, told, or accepted by everyone who contemplates it... Names blend with each other, mix, appear, disappear and resurrect; however any human has a name" (Bulgakov, 1953: 163).

According to $\mathrm{S}$. Bulgakov a name giving process is an act of birth, name-idea's connection with matter. Despite name's affiliation to the individual being core, it is only a shell, even though the shell is enormous and determines owner's being. The potential and real beings are distinguished in a name giving act: "a man obtains a name like he obtains his body". Any new level of ascetic practice is associated with a new name receiving in the Orthodox tradition: everyone who is accepted to the monastic rows receives a new Christian name, whose holder is glorified by a church and is a saint. Consequently, "To those who win the victory I will give some of the hidden manna. I will also give each of them a white stone on which is written a new name that no one knows except the one who receives it" (Rev. 2:17).

Transformation, resurrection should be a creative comprehensive process of a name change, a true name revelation: "that is not invented by people, but is obtained by an eternal creative God's act, and has a Sophia character" (Bulgakov, 1953: 172). A death is name's separation from its holder (the names are mentioned separately in a church). Meanwhile a death of a previous name becomes only the potential of past. As a result any renaming is not only a name change, but also the replacement of its holder.

A name determines a human essence, his whole being. As a consequence, there are good and evil names: "on each of its (beast's) heads there was a name that was insulting to God" (Rev. 13:1).

The human names are inscribed on Heaven, not in earth being, but in eternal transcendental being: But don't be glad because the evil spirits obey you; rather be glad because your names are written in heaven (Luke 10:20)".

A name is considered on sacral, ontological and social levels by $P$. Florensky. A name has some sacral meaning and has profound influence on its owner's further fate: "A name predicts a further fate, introduces spiritual and corporal features into it a life of a folklore character as well as in real human existence" (Florensky, 2000: 187). There are numerous references to the bright expression by the saints of their names' essence in the lives of saints, prologues and church songs. "A name corresponds to a life" is a common formula of the lives of saints; a life is 
according to a name, not vice versa. A name is evaluated by the Orthodox Church and all Orthodox believers as a type, as a spiritual norm of individual being, as an idea; hence a saint is the best example of its embodiment" (Florensky, 2000: 188). A name is an ontologically basic item; therefore any saint is a secondary item.

A name is the main determination of Self on the ontological level, as Self is posed in a name and on behalf of a name in front of itself, consequently it is accepted to everyone by this position. Without a name a person "is not a person for himself, for different members of a society, without it he is only a potential of future abilities" (Florensky, 2000: 206). A name becomes the basic and the deepest phenomenon of a person in objective world: a way in the human world penetration and communication renewal can be seen only in a name. A personal ontological form which determines further soul's spiritual building is expressed by a name. Hence the names express the different types of personal being.

A name provides an opportunity to save social memory as well as individual one: the ultimate name's lost means social and historical death, the final disappearance from human history, and controversy entrance into history, finding a new place in it, new reality's creation always begins from "a new name's creation". The name's reproduction in the social memory's context implies an owner's social image preservation as well as spiritual conservation, the highest level of which is "eternal memory of church and God. If the names are in God's memory it means the possibility of their eternal being, however, the final break with God means a name's elimination from the Book of Life" (Florensky, 2000: 207).

\section{Conclusions}

To conclude the pagan tradition of name giving is based on spiritual unity of human and natural world which transforms a name into a special charm for an owner that determines the further fate of its holder. A pagan name is a family name which embodies the deep sacral treasure of ethnical and cultural spirituality. The Christian tradition of sacrificed names' usage examines a name not only in the light of spiritual protection of a guardian, but as a milestone for further spiritual changes. The Orthodox philosophy of a name expands a horizon of ethnical and national culture of Ukrainian onomastic science with application to spiritual heritage of Hellenic and Judaic culture of name giving.

\section{REFERENCES}

Bulgakov, S. (1989). Pravoslaviye: ocherki ucheniya pravoslavnoy tserkvi. Paris: YMCA-PRESS, 409 p. (In Russian)

Bulgakov, S. (1953). Filosofiya imeni. Paris: YMCA-PRESS, 279 p. (In Russian)

Chrysostom, John (2001). Conversations on the Book of Genesis. 21 $1^{\text {st }}$ Conversation. Retrieved from https://azbyka.ru/ otechnik/loann Zlatoust/tolk_01/21

Chuchka, P. (2011). Slovyanski osobovi imena ukrayintsiv: istoryko-etymolohichnyy slovnyk. Uzhhorod: Lira, 428 p. (In Ukrainian)

Khrypko, S., latsenko, G. (2019). Philosophy of a Name: Ukrainian Context. BEYTULHIKME: An International Journal of Philosophy. 9 (2): 437-451. DOI: https://doi.org/10.18491/ beytulhikme.1477 (In English).

Florensky, P. (2000). Imena. Metafizika imen v istoricheskom osveshchenii In: Soch. V 4-kh t.T.3 (2). Moscow: Mysl, 623 p. (In Russian)

Franko, I. (1982). Prychyny do ukrayinskoyi onomastyky. In: Ivan Franko. Zibr. tv.: V 50 t. Kyiv, Vol. 36: 391-427. (In Ukrainian)
Gerasimchuk, V., Nechiporenko, A. (2002). Antroponimy: istoriya $i$ suchasnist. Kamyanets-Podilskyy, 152 p. (In Ukrainian) Khudash, M. (1977). Z istoriyi ukrayinskoyi antroponimiyi. Kyiv: Naukova dumka, 235 p. (In Ukrainian)

Losev, A. (1990). Filosofiya Imeni. Moscow: MGU Publishing. (In Russian)

Lozko, G. (1998). Imenoslov: imena slovyanski, istorychni ta mifolohichni. Kyiv: Svaroh, 176 p. (In Ukrainian)

Lozko, G. (2011). Ridni imena. Slovyanskyy imenoslov. Ternopil: Mandrivets, 368 p. (In Ukrainian)

Plato (1994). Kratil [Kratylos]. In: Sobr. soch.: V 4 t. Moscow: Mysl, Vol.1. Retrieved from http://www.odinblago.ru/platon_5/4. (In Russian)

Savitska, S., Savitski, O. (2012). Imenoslov: Slovyanski imena ta nazvy. Ternopil, 400 p. (In Ukrainian)

Saint Augustine (2006). Khristianskaya nauka ili Osnovaniya Svyashchennoy Germenevtiki i Tserkovnogo krasnorechiya. St.Petersburg: Bibliopolis, 510 p. (In Russian)

Shibutani, T. (2007). YA-kontseptsiya. In: Psikhologiya samosoznaniya. Samara: BAKHRAKH-M, 245-270 (In Russian)

Skripnik, L., Dziatkivska, N. (1996). Vlasni imena lyudey. Kyiv: Naukova dumka, 336 p. (In Ukrainian)

Suchomlin, I. (1970). Ukrayinski prizvyska lyudey yak vlasni rodovi nazvy. Hovory i onomastyka Naddnipryanshchyny. Dnipropetrovsk: 30-58. (In Ukrainian)

Bibliya (The Bible) (2004). Knyhy Svyashchennoho pysannya Staroho ta novoho Zavitu. Kyiv: Vydannya Kyyivskoyi Patriarkhiyi UPTS KP, 1407 p. (In Ukrainian)

Khristianstvo (1995). Entsiklopedicheskiy slovar: (In 3 Vol.). Moscow: Bolshaya Rossiyskaya entsiklopediya, 863 p. (In Russian)

Slova prepodobnogo Simeona Novogo Bogoslova. (1890). Issue 2. Slovo 68. Moscow, Pp. 190. (In Russian)

Zajvoronok, V. (2006). Znaky ukrayinskoyi etnokultury: Slovnyk-dovidnyk. Kyiv: Dovira, 703 p. (In Ukrainian)

Zajvoronok, V. (2007). Ukrayinska etnolinhvistyka: Narysy. Kyiv: Dovira, 262 p. (In Ukrainian)

\section{LIST OF REFERENCE LINKS}

Августин Блаженный. Христианская наука или Основания Священной Герменевтики и Церковного красноречия. Санкт-Петербург: Библиополис, 2006. 510 с.

Біблія: книги Священного писання Старого та нового Завіту. Київ: Видання Київської Патріархії УПЦ КП, 2004. 1407 с. Булгаков С. Н. Православие: очерки учения православной церкви. 3-е изд. Париж: YMCA-PRESS, 1989. 409 с.

Булгаков С. Н. Философия имени. Париж: YMCA-PRESS, 1953. $279 \mathrm{c}$.

Герасимчук В., Нечипоренко А. Антропоніми: історія і сучасність: Навч. посібник. Кам'янець-Подільський, 2002. 152 с. Жайворонок В. Знаки української етнокультури: Словник-довідник. Київ: Довіра, 2006. 703 с.

Жайворонок В. В. Українська етнолінгвістика: Нариси. Київ: Довіра, 2007. 262 с.

Иоанн Златоуст. Беседы на книгу Бытия. Беседа 21. URL: https://azbyka.ru/otechnik/loann_Zlatoust/tolk_01/21 (дата звернення: 25.05.2019)

Лозко Г. С. Іменослов: імена слов'янські, історичні та міфологічні. Київ: Сварог, 1998. 176 с.

Лозко Г. С. Рідні імена. Слов'янський іменослов. Тернопіль: Мандрівець, 2011. 368 с.

Лосев А. Ф. Философрия Имени. Москва: Изд-во Моск. унта, 1990.

Платон. Кратил. Собр. соч.: В 4 m. Москва: Мысль, 1994. T. 1. URL: http://www.odinblago.ru/platon_5/4 (дата звернення: 25.05.2019)

Савіцька С., Савицький О. Іменослов: Слов'янські імена та назви. Тернопіль, 2012. 400 с. 
Скрипник Л. Г., Дзятківська Н. П. Власні імена людей. Київ: Наук. думка, 1996. 336 с.

Слова преподобного Симеона Нового Богослова. Вып. 2. Слово 68. Москва, 1890. С. 190.

Сухомлин І. Д. Українські прізвиська людей як власні родові назви. Говори і ономастика Наддніпрянщини. Дніпропетровськ, 1970. С. 30-58.

Флоренский П. А. Имена. Метафизика имен в историческом освещении. Флоренский П. Соч. В 4-х М. Т.3 (2). Москва: Мысль, 2000. 623 с.

Франко І. Причини до української ономастики. Іван Франко. Зібр. тв.: В 50 m. Київ, 1982. Т. 36. С. 391-427
Христианство: Энциклопедический словарь: в 3 тт. Т. 1. Москва: Большая Российская энциклопедия, 1995. 863 с.

Худаш М. Л. 3 історії української антропонімії. Київ: Наук. думка, 1977. 235 с.

Чучка П. П. Слов'янські особові імена українців: історикоетимологічний словник. Ужгород: Ліра, 2011. 428 с.

Шибутани Т. Я-концепция. Психология самосознания: Хресmоматия. Самара: Изд. Дом "БАХРАХ-М", 2007. С. 245-270.

Khrypko S., latsenko G. Philosophy of a Name: Ukrainian Context. BEYTULHIKME: An International Journal of Philosophy. 2019. № 9 (2). P. 437-451. DOI: https://doi.org/10.18491/ beytulhikme. 1477

\section{Ломачинська Ірина,}

Київський університет імені Бориса Грінченка (м. Київ, Украӥна) e-mail: lomachinskairina@ukr.net, ORCID 0000-0003-2537-6322

Хрипко Світлана,

Київський університет імені Бориса Грінченка (м. Київ, Украӥна)

e-mail:s.khrypko@kubg.edu.ua,ORCID 0000-0001-9426-4549

Яценко Ганна,

Наиіональний університет кораблебудування імені адмірала Макарова (м. Миколаїв, Україна) e-mail: iats2601@gmail.com,ORCID0000-0002-8675-5118

\section{ТРАНСФОРМАЦІЯ УКРАЇНСЬКОГО ІМЕНОСЛОВА: ІСТОРИЧНИЙ ЗРІЗ}

Стаття присвячена ціннісному зрізу проблеми актуалізації християнської домінанти в духовно-семантичному просторі культури ім'янаречення в українській антропонімістичній традиції, а також історико-філософському аналізу особливостей присутності духовної складової в процесі створення та функціонування особистих імен в українській духовній культурі дохристиянської доби. Апріорність актуальності проблеми підтверджує той факт, що ім'я є одним із найважливіших символів в усвідомленні людиною своєї самості. Антропоніми (власні імена людей) споконвіків були і є чи не найуживанішим лексичним феноменом в усі епохи і в усіх народів, що підтверджує постійну екзистенційну нагальність даної теми як в індивідуальному, так і в суспільному зрізі осмислення. Сферою наукового осмислення є генеза і вияви українського ономастикону. Осмислюється популярність давніх імен і обсяг розуміння інформованості в питанні істинності духовних коренів того чи іншого давнього імені. Генеральною ідеєю роботи є твердження, що, зберігаючи духовні витоки язичницької традиції, український національний ономастикон сформувався значною мірою і на православних ціннісних засадах, що зумовлено історичними особливостями розвитку національного релігійно-культурного простору. Акцентується значимість імені як філософського, культурного та духовно-історичного феномена. Мета роботи - системно репрезентувати трансцендентну специфіку власних імен та шляхом структурного аналізу 3 залученням герменевтичної методології висвітлити специфіку появи та духовну складову в зрізі елітно-сакральних, елітно-світських та народних імен в давній етнічній традиції українців. Проаналізувати вектори значимості тих чи інших духовних коренів в культурі ім'янаречення. Висновкові результати даної публікації втілюють наступні узагальнення і перспективні константи:

- На онтологічному рівні ім'я є найбільш суттєвим самопроявом Я.

- У соціальному плані ім'я є можливістю збереження соціальної пам'яті.

- Двополюсний контекст українського ономастикону репрезентує язичницька традиція іменування, основана на одухотвореній єдності людини з навколишнім природнім світом, що робить ім'я своєрідним духовним оберігом.

-Християнська традиція освяченого імені формує ім'я не лише як духовний захист сакралізованого покровителя, але й як стимул до подальших духовних змін.

Ключові слова: ім'я; особисте ім'я; фрілософрія імені; християнська традиція імені; духовність; духовна традиція; антропоніміка; етнокультура.

(c) Lomachinska Irina, Khrypko Svitlana, latsenko Ganna

Надійшла до редакції: 03.06.2019

Прийнята до друку: 17.07.2019 